\title{
Implementasi Sistem Kendali PID pada Gimbal Kamera 2- sumbu dengan Aktuator Motor Brushless
}

\author{
Tri Kuntoro Priyambodo*1 \\ Departemen Ilmu Komputer dan Elektronika, \\ Fakultas MIPA Universitas Gadjah Mada, Yogyakarta, Indonesia \\ e-mail: *11mastri@ugm.ac.id
}

\begin{abstract}
Abstrak
Pesawat tanpa awak telah banyak dikembangkan untuk kepentingan dalam berbagai bidang. Salah satu bidang pemanfaatannya adalah pada bidang fotografi udara. Pengambilan gambar menggunakan pesawat tanpa awak, selain membutuhkan kamera yang baik, juga membutuhkan komponen gimbal sebagai pengendalian stabilitas kamera. Gimbal kamera sebagai pengendali stabilitas membantu kamera untuk memperoleh orientasi gambar yang lebih baik. Gimbal kamera berfungsi untuk mengurangi getaran maupun gerakan yang akan mengganggu kamera saat pengambilan gambar yang diakibatkan oleh pergerakan pesawat tanpa awak itu sendiri. Dalam upaya mendapatkan stabilitas kamera secara maksimal, diperlukan sistem kendali. Pada penelitian ini dikembangkan sebuah system kendali gimbal kamera dengan metode PID yang diimplementasikan dalam sebuah mikrokontroller dan menggunakan motor brushless sebagai aktuatornya. Pemilihan motor brushless sebagai aktuator gimbal dikarenakan motor brushless memiliki beberapa kelebihan diantaranya adalah memiliki efisiensi yang tinggi, lebih tahan lama dan memiliki respon yang baik. Hasil akhir penalaan sudut roll didapatkan nilai konstanta $\mathrm{Kp}=0.37, \mathrm{Ki}=0.01, \mathrm{Kd}=0.29$ dengan ratarata waktu respon $=0.8$ detik. Sedangkan pada sudut pitch didapatkan nilai konstanta $\mathrm{Kp}=$ $0.55, K i=0.01, K d=0.29$ dengan rata-rata waktu respon $=0.7$ detik.
\end{abstract}

Kata kunci-fotografi udara, pemetaan, pesawat tanpa awak, Ziegler-Nichols

\begin{abstract}
Unmanned Aerial Vehicle has been developed for the benefit in various fields. One of them is in the field of aerial photography. Taking pictures using unmanned aircraft, in addition to a good camera, also requires gimbal camera components as camera stability controller. Gimbal camera as stability controller helps the camera to obtain a better image orientation. Gimbal camera serves to reduce vibration and movement that would interfere with the camera when taking pictures caused by the movement of the drone itself. In an effort to get to the maximum camera stability, it is necessary a control systems. This study developed a camera gimbal control system with PID method. The controller is implemented in a microcontroller and uses a brushless motor as the actuator. The brushless motor is chosen because it has several advantages including the high-efficiency, longer lasting and have a good response. In order to facilitate the search for a constant value control, in this study is used Ziegler-Nichols tuning method. The final tuning on roll angle gives constant values $K p=0: 37, K i=0: 01$, and $K d=$ $0: 29$ with average response time $=0.8$ seconds. While tuning on the pitch angle gives constant values $K p=0: 55, K i=0: 01$, and $K d=0: 29$ with average response time $=0.7$ seconds.
\end{abstract}

Keywords - aerial photography, mapping, unmanned aerial vehicle, Ziegler-Nichols 


\section{PENDAHULUAN}

$\mathrm{P}^{\mathrm{s}}$ esawat tanpa awak (Unmanned Aerial Vehicle) adalah pesawat terbang tanpa awak yang menggunakan gaya aerodinamik untuk dapat terbang [1]. Pesawat tanpa awak ini mampu terbang secara mandiri (autonomous) ataupun dibantu dengan dikemudikan jarak jauh menggunakan remote control. Pesawat tanpa awak kini telah dimanfaatkan dalam berbagai bidang kehidupan, antara lain pemantauan, patroli udara dan juga photografi udara [2]. Pengambilan gambar menggunakan pesawat tanpa awak dianggap memberikan hasil gambar yang lebih relevan sebagai bahan studi kasus pada daerah dengan masalah tertentu seperti daerah rawan banjir [3]. Untuk membantu mendapatkan gambar yang baik, maka pesawat tanpa awak sebaiknya dilengkapi dengan komponen gimbal yang akan menjaga kamera tetap berada pada posisi yang tepat [4][5].

Gimbal adalah alat mekanik yang terdiri dari dua atau lebih cincin yang dipasang pada sumbu tertentu untuk menjaga ketabian suatu obyek pada posisi tertentu. Gimbal saat ini banyak diaplikasikan pada beberapa bidang seperti bidang navigasi, roket maupun photografi. Dalam bidang photografi, gimbal digunakan untuk menjaga dan mempertahankan posisi kamera pada sudut tertentu sehingga kamera dapat menghasilkan gambar dengan kesan yang lebih halus. Gimbal akan mempertahankan posisi kamera dengan cara membaca sudut kamera tersebut untuk kemudian dengan mekanik yang ada akan mengatur sudut kamera kembali ke posisi yang diinginkan sehingga Nampak seperti tidak terpengaruh oleh gangguan luar [6]. Pada penelitian ini gimbal dibangun menggunakan actuator berupa motor brushless. Motor brushles dipilih karena motor brushless memiliki beberapa keunggulan dibandingkan dengan jenis motor lainnya antara lain memiliki efisiensi yang tinggi, lebih tahan lama dan memiliki respon yang baik [7].

Sistem kendali dibutuhkan untuk dapat menjaga posisi kamera pada gimbal. PID adalah salah satu metode kendali yang paling sering digunakan dalam industry kendali. Hal ini dikarenakan metode kendali PID ini mempunyai struktur yang sederhana, mudah untuk dipelihara dan mudah untuk di tala ulang [6]. Selain itu, metode system kendali PID juga dapat digabungkan dengan algoritme lain seperti algoritme Ant Colony Optimization [8][9], Particle Swarm Optimization [10], fuzzy [11], neural network [12] dan algoritme-algoritme lainnya yang hingga saat ini masih terus dikembangkan [13].

\section{METODE PENELITIAN}

Motor brushless sebagai actuator menjadi bagian penting untuk dapat dikendalikan demi mendapat pergerakan gimbal yang baik. Pada umumnya, brushless motor dikendalikan menggunakan komponen ESC (Electronic Speed Controller). Hanya saja, komponen ESC ini hanya bisa mengatur kecepatan putaran brushless motor tanpa bisa mengatur arah putaran motor. Di sisi lain, aplikasi brushless motor untuk gimbal kamera membutuhkan pengaturan tidak hanya kecepatan putaran motor brushless namun juga arah dari putaran motor tersebut, untuk itu komponen ESC tidak dapat digunakan dalam penelitian gimbal kamera ini dan harus dibuat kendali tersendiri untuk dapat mengatur kecepatan dan arah putar dari motor brushes sesuai yang diinginkan.

Motor brushless DC (BLDC) digerakkan dengan cara memberikan sinyal listrik 3 fasa pada statornya. Sinyal listrik 3 fasa ini berbentuk mirip dengan sinyal AC, hanya saja sinyal AC disini dibentuk dengan sumber dari sinyal DC. Untuk mendapatkan sinyal yang diharapkan ini digunakan inverter 3 fasa untuk mengubah tegangan DC menjadi tegangan AC 3 fasa.

IJEIS Vol. 7, No. 2, October 2017 : $111-126$ 


\subsection{Metode Six-Step}

Salah satu cara menggerakkan motor brushless adalah dengan metode six-step. Six-step merupakan metode yang paling sering digunakan dalam pengendalian BLDC komersial. Metode ini dipilih karena mudah untuk diimplementasikan sehingga tidak membebani proses dari mikrokontroller nantinya. Metode ini disebut metode six-step karena mampu menciptakan gelombang trapezoid atau square yang menyerupai gelombang sinusoidal, digunakan PWM square yang terdiri dari 6 bagian yakni 2 bagian positif, 2 bagian negatif, dan 2 bagian floating.

Gelombang kotak yang digunakan untuk menggerakkan motor brushless digambarkan pada Gambar 1.

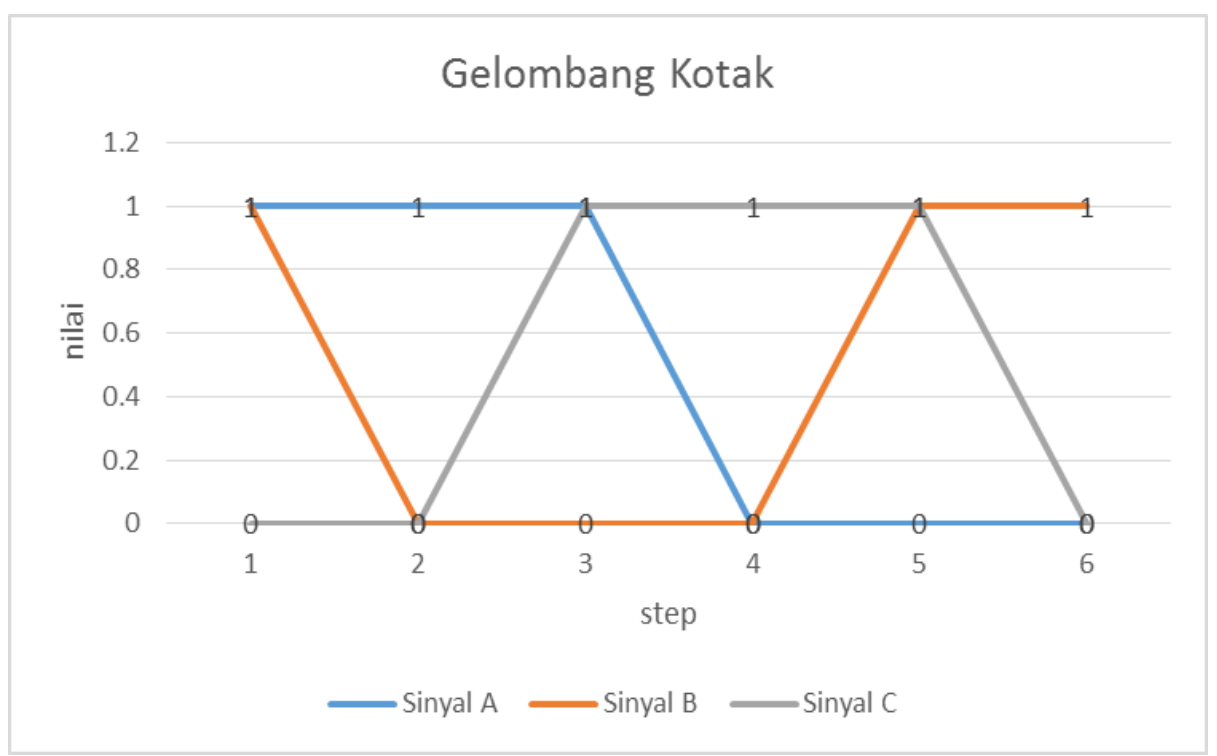

Gambar 1 Gelombang kotak untuk menggerakkan motor brushless.

Dapat pula dituliskan ke dalam bentuk table seperti yang disajikan pada Table 1.

Tabel 1 Sinyal gelombang kotak untuk pergerakan motor brushless

\begin{tabular}{|l|l|l|l|}
\hline $\begin{array}{c}\text { Step } \\
\text { ke- }\end{array}$ & A & B & C \\
\hline $\mathbf{1}$ & 1 & 1 & 0 \\
\hline $\mathbf{2}$ & 1 & 0 & 0 \\
\hline $\mathbf{3}$ & 1 & 0 & 1 \\
\hline $\mathbf{4}$ & 0 & 0 & 1 \\
\hline $\mathbf{5}$ & 0 & 1 & 1 \\
\hline $\mathbf{6}$ & 0 & 1 & 0 \\
\hline
\end{tabular}

Dengan metode six step tersebut, motor brushless akan bergerak sejauh 60 derajat untuk 1 periodenya. Sesuai namanya, dalam satu periode metode six step ini terbagi kedalam 6 tahapan atau step, sehingga setiap stepnya akan mengakibatkan pergerakan motor sejauh 10 derajat. 


\section{2 Metode Sinusoidal}

Sebagai pengembangan dari metode six-step tersebut, digunakan pendekatan gelombang sinus untuk dapat menggerakkan motor brushless dengan lebih halus atau dalam sudut yang lebih kecil. Hal ini dapat dilakukan dengan cara mengubah nilai gelombang kotak dalam 6 step tersebut dengan sinyal sinusoidal yang memiliki step lebih banyak. Gelombang kotak yang digunakan diubah menjadi gelombang sinus dengan cara pendekatan rentang sebesar nilai PWM mikrokontroller yang digunakan.

Dalam penelitian ini digunakan PWM 8 bit sehingga rentang nilai yang digunakan untuk membuat gelombang sinusoidal tersebut memiliki rentang 0 hingga 255. Untuk mendapatkan deretan nilai PWM yang membentuk gelombang sinusoidal tersebut digunakan persamaan (1).

$$
x(i)=\sin \left(2 * i * \frac{\pi}{\mathbb{N}}\right)+127
$$

dengan :

$i=$ indeks

$N=$ jumlah data

Dalam implementasi, nilai PWM memiliki rentang dari 0 hingga 255. Dalam percobaan pertama pada arduino akan dibagi menjadi 48 step. Ternyata diperoleh hasil pergerakan motor yang masih kurang halus, sehingga jumlah step dinaikkan hingga didapatkan pergerakan motor brushless yang cukup halus. Kenaikan jumlah step ini akan meningkatkan presisi dari pergerakan motor, namun di sisi lain juga akan mengurangi kecepatan respon dari motor tersebut.

Seperti yang telah dijelaskan sebelumnya, dalam pengendalian motor brushless dibutuhkan sinyal masukan berupa tengan 3 fase. Dalam rangaka mendapatkan nilai sinyal 3 fasa dengan beda fasa yang sama besar antara ketiganya, maka dibuat lah 3 sinyal tersebut dari serangkaian nilai yang telah didapat dari persamaan (1) dengan indeks awal yang berbeda. Sebagai contoh, untuk data dengan jumlah step 48 step, maka masing-masing fase akan dimulai dari indeks 0 , indeks 16 dan indeks 32. Sedangkan untuk data dengan jumlah step 256 step, maka masing-masing fase akan dimulai dari indeks 0 , indeks 85 dan indeks 170. Dengan demikian, contoh data di atas dapat ditampilkan dalam bentuk grafik seperti yang disajikan pada Gambar 2 dan Gambar 3. Nilai lompatan indeks dalam larik hasil perhitungan tersebut akan mempengaruhi seberapa besar motor brushless akan bergerak.

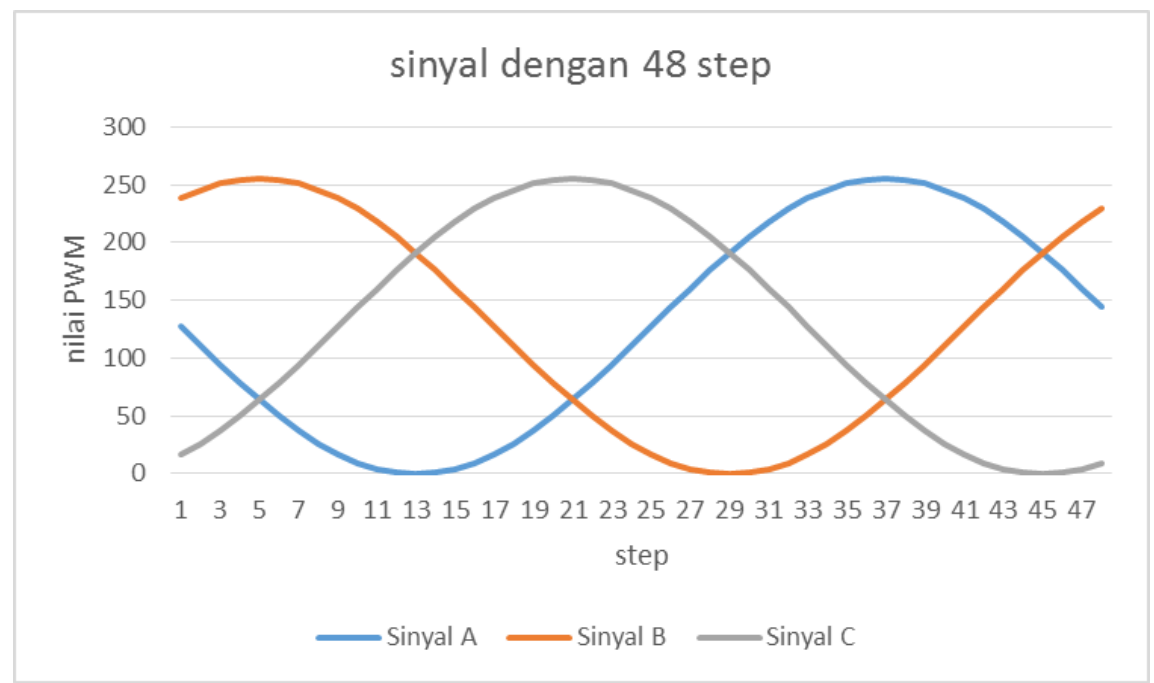

Gambar 2 Sinyal sinusoidal dengan 48 step

IJEIS Vol. 7, No. 2, October 2017 : $111-126$ 


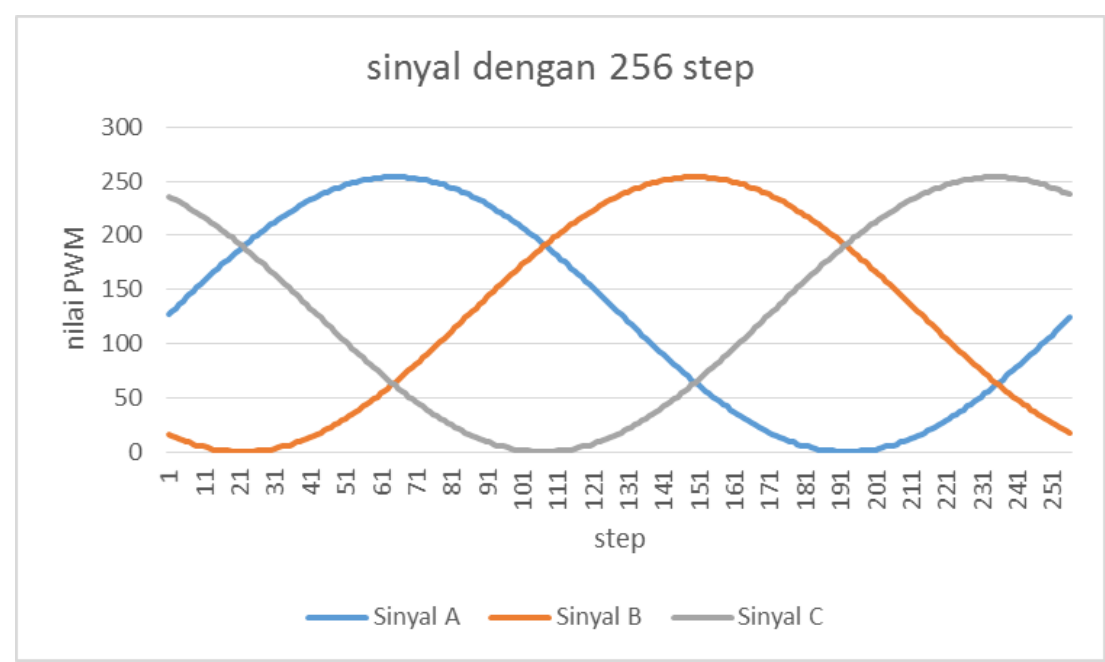

Gambar 3 Sinyal sinusoidal dengan 256 step

\subsection{Sistem Kendali Gimbal Kamera}

Sistem kendali yang dirancang pada penelitian ini adalah sistem kendali PID yang akan digunakan untuk mengendalikan gimbal kamera 2 sumbu agar berada pada orientasi yang diharapkan. 2 sumbu yang dikendalikan pada penelitian ini adalah sumbu-x dan sumbu-y. Mikrokontroler sebagai otak pemrosesan system dibangun menggunakan arduino mega. Sedangkan ragkaian pengendalinya terdiri dari rangkaian regulator tegangan 5 volt dan 2 buah rangkaian driver motor menggunakan IC L298. Gambar 4 menyajikan arsitektur kendali gimbal kamera yang dibangun. Rancangan sistem kendali yang ditunjukkan pada Gambar 5 diharapkan mampu meminimalisir ganggunan yang terjadi baik gangguan internal maupun gangguan eksternal.

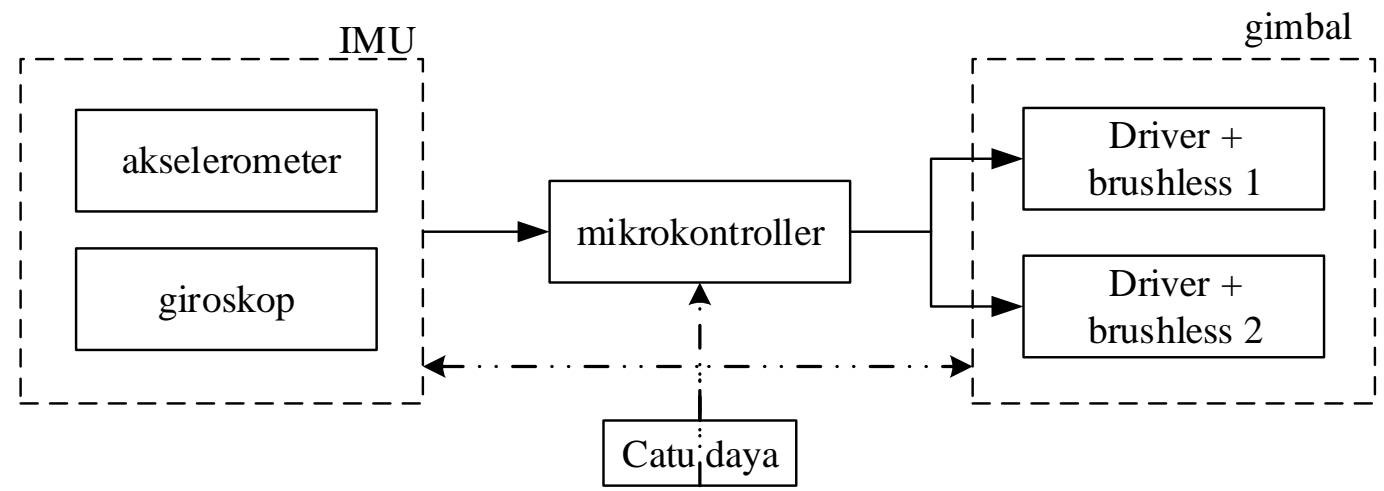

Gambar 4 Diagram arsitektur kendali gimbal 


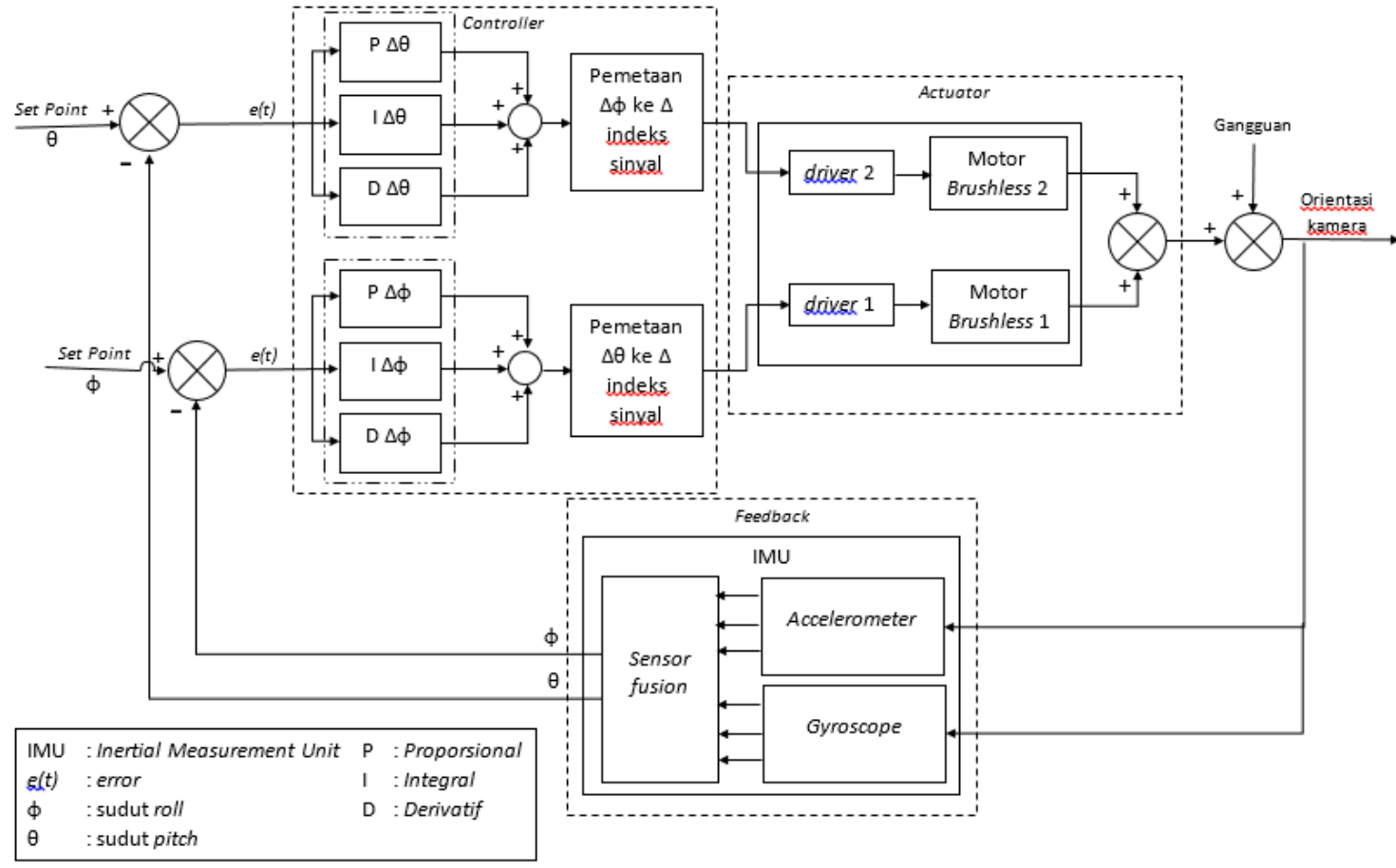

Gambar 5 Diagram kendali gimbal

Gambar 4 menampilkan diagram blok elektronikdari sistem gimbal yang dibangun. Seperti disajikan pada Gambar 4, terlihat bahwa input sistem adalah 2 buah sensor, yaitu sensor akselerometer dan giroskop. Selanjutnya input-input tersebut akan diproses oleh perangkat pemrosesan yaitu arduino. Selain untuk memproses sinyal-sinyal masukan, perangkat pemroses ini juga digunakan untuk mengatur pergerakan dari 2 buah motor brushless DC (BLDC) sebagai aktuator sistem. 2 buah motor brushless DC ini akan digunakan untuk mengatur orientasi dari kamera yang telah dipasangkan pada mekanik gimbal kamera. Pengendalian orientasi kamera ini dilakukan menggunakan metode PID.

Sistem kendali PID yang dibangun akan digunakan untuk mengatur 2 buah motor brushless DC yang akan mengatur posisi orientasi dari kamera. Masing-masing motor akan mengubah posisi orientasi kamera pada suatu sumbu tertentu, untuk itu digunakan 2 buah sistem kendali PID untuk dapat mengatur pergerakan 2 buah motor brushless DC agar posisi kamera berada pada posisi yang diinginkan.

Diagram blok system kendali disajikan pada Gambar 5. Sistem kendali yang dibangun adalah sistem kendali kalang tertutup (closed-loop) yang akan mendapatkan masukan berupa error posisi kamera, yaitu berupa selisih sudut pitch dan selisih sudut roll. Selisih sudut disini adalah perbedaan nilai yang dihasilkan oleh nilai sudut orientasi kamera dan nilai set point. Orientasi kamera dapat dideteksi menggunakan 2 buah sensor, yaitu sensor akselerometer dan sensor giroskop. Bacaan kedua sensor tersebut kemudian akan dimasukkan ke dalam algoritme sensor fussion agar didapatkan nilai orientasi kamera. Nilai error hasil perhitungan pada system tersebut kemudian akan digunakan dalam perhitungan kendali menggunakan persamaan kendali PID seperti yang disajikan dalam persamaan (2).

$$
u(t)=K_{p} e(t)+K_{i} \int_{0}^{t} e(t) d t+K_{d} \frac{d}{d t} e(t)
$$

IJEIS Vol. 7, No. 2, October 2017 : $111-126$ 
Hasil nilai perhitungan PID ini akan digunakan untuk mengatur lompatan indeks dari larik hasil perhitungan dalam persamaan (1), dimana nilai lompatan indeks tersebut akan mempengaruhi seberapa besar motor brushless akan bergerak. Dalam rangka mendapatkan konstanta kendali yang digunakan pada persamaan (2), pada penelitian ini digunakan penalaan Ziegler-Nichols metode 2, yaitu metode osilasi. Hal ini dikarenakan system yang digunakan adalah system dengan kalang tertutup (closed loop) yang mana memiliki karakteristik dengan step respon berupa osilasi (tidak membentuk kurva S). Apabila sistem memiliki step respon berupa kurva-S, maka penalaan akan lebih tepat jika menggunakan Ziegler-Nichols metode 1.

\section{HASIL DAN PEMBAHASAN}

Penalaan sistem kendali PID dilakukan menggunakan metode Ziegler-Nichols didasarkan pada kesederhanaan dari step respon sistem [14]. Metode Ziegler-Nichols ini dikembangkan dari metode trial and error dan memiliki dua cara, yaitu metode osilasi dan kurva reaksi. Metode penalaan ini akan menentukan nilai penguatan proportional (Kp), waktu integral (Ti), dan waktu derivative (Td). Untuk mendapatkan nilai Kcr dapat digunakan perhitungan menggunakan model system atau percobaan secara langsung. Gambar 6 menampilkan contoh hasil penalaan Ziegler Nichols dengan metode osilasi.

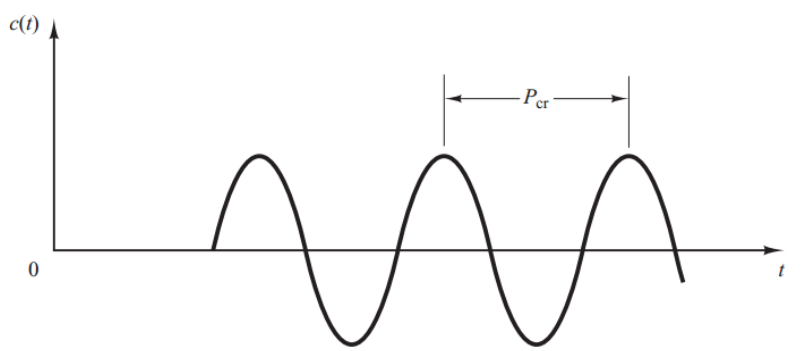

Gambar 6 Penalaan Ziegler-Nichols metode osilasi [15]

Langkah-langkah untuk melakukan penalaan konstanta PID menggunakan metode osilasi pada penalaan Ziegler-Nichols adalah sebagai berikut:

1) $\mathrm{Ki}$ dan $\mathrm{Kd}$ diberi nilai 0

2) Nilai Kp dinaikkan terus sampai sistem mengalami osilasi yang stabil. Nilai Kp yang diperoleh tersebut ditulis sebagai Kcr. Nilai Kp awal ini dapat ditentukan dengan cara perhitungan Routh dari model sistem atau dilakukan dengan percobaan secara langsung. Sedangkan kenaikan nilai dilakukan dengan besaran nilai berbeda-beda disesuaikan dengan kebutuhan sistem, yaitu nilai terkecil yang dapat mempengaruhi respon sistem tersebut.

3) Nilai Pcr merupakan periode osilasi seperti yang ditunjukkan pada Gambar 7.

4) Nilai Kp, Ki, Kd dihitung berdasarkan Tabel 2.

Tabel 2 Model penalaan konstanta PID dengan metode Ziegler-Nichols metode osilasi [15]

\begin{tabular}{|c|c|c|c|}
\hline $\begin{array}{c}\text { Tipe } \\
\text { Kendali }\end{array}$ & $\mathrm{Kp}$ & $\mathrm{Ki}$ & $\mathrm{Kd}$ \\
\hline $\mathrm{P}$ & $0,5 \mathrm{Kcr}$ & $\infty$ & 0 \\
\hline PI & $0,45 \mathrm{Kcr}$ & $\mathrm{Pcr} / 1,2$ & 0 \\
\hline PID & $0,6 \mathrm{Kcr}$ & $0,5 \mathrm{Pcr}$ & $0,125 \mathrm{Pcr}$ \\
\hline
\end{tabular}


Penalaan menggunakan metode osilasi Ziegler Nichols menghasilkan respon sistem yang kurang cepat dan kurang sesuai untuk sistem kendali gimbal kamera. Agar diperoleh respon sistem seperti yang diharapkan dilakukan penalaan yang lebih halus (fine-tuned). Penalan kedua ini dilakukan secara langsung (manual) pada system yang dibangun, yaitu gimbal kamera. Hal ini selain diharapkan dapat memperhalus respon system juga agar dapat dilihat secara riil bagaimana system yang dibangun tersebut bekerja.

Dari hasil penalaan kedua tersebut, didapatkan sistem kendali dengan respon yang baik dan mampu menahan orientasi kamera pada sudut yang diharapkan yaitu pada sudut 00 . Pada penalaan sudut roll diperoleh nilai konstanta $\mathrm{Kp}=0.37, \mathrm{Ki}=0.01, \mathrm{Kd}=0.29$ dengan rata-rata waktu respon $=0.8$ detik, yang ditampilkan pada Gambar 7. Sedangkan pada sudut pitch diperoleh nilai konstanta $\mathrm{Kp}=0.55, \mathrm{Ki}=0.01, \mathrm{Kd}=0.29$ dengan rata-rata waktu respon $=0.7$ detik.

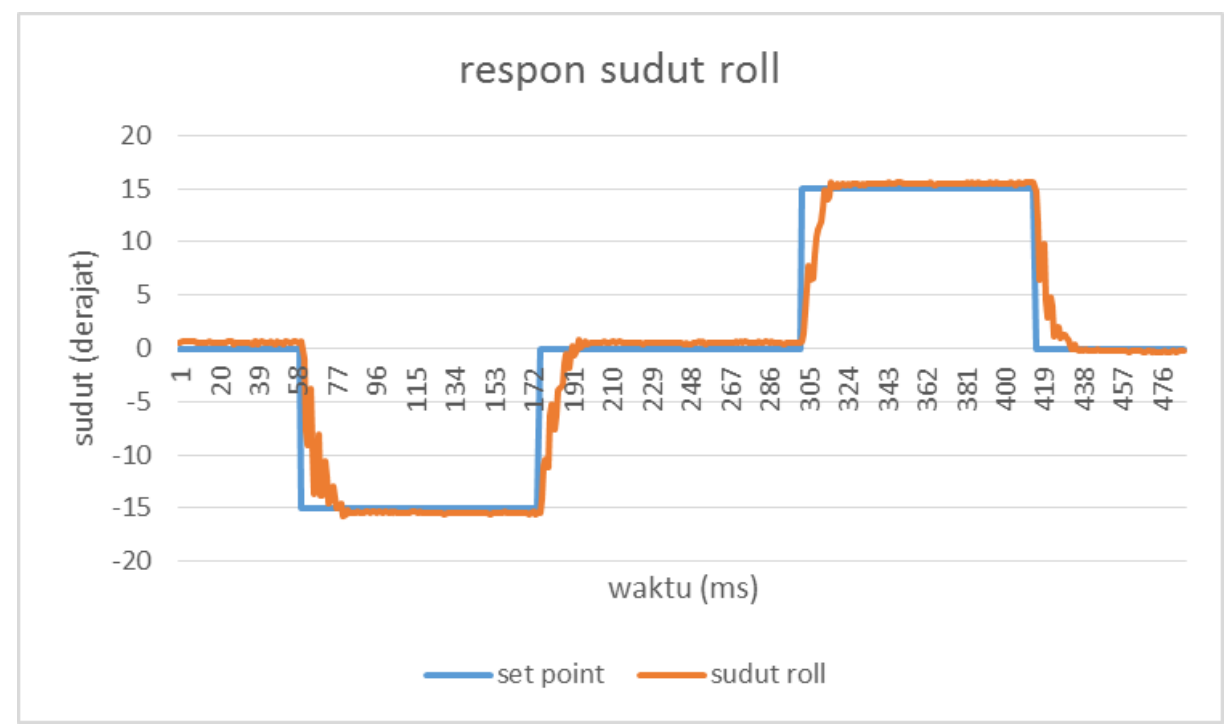

Gambar 7 Respon sudut roll terhadap waktu

\section{KESIMPULAN}

Telah berhasil dibuat sebuah sistem kendali gimbal kamera berbasis mikrokontroler yang menggunakan motor brushless sebagai aktuatornya. Pengendalian motor brushless tersebut dilakukan dengan input larik angka yang membentuk sinyal sinusoidal. Perubahan indeks pada larik tersebut akan mengatur pergerakan dari motor brushless. Sistem kendali akan menentukan perubahan indeks pada larik tersebut agar didapat pergerakan motor brushless sesuai yang diharapkan.

Penalaan konstanta kendali pada penelitian ini dicari menggunakan pendekatan metode Ziegler Nichols. Hasil penalaan menggunakan metode Ziegler Nichols digunakan sebagai nilai awal pada penalaan selanjutnya (fined-tune) sehingga didapatkan respon sistem yang lebih baik. Hasil akhir penalaan sudut roll didapatkan nilai konstanta $\mathrm{Kp}=0.37, \mathrm{Ki}=0.01, \mathrm{Kd}=0.29$ dengan rata-rata waktu respon $=0.8$ detik. Sedangkan pada sudut pitch didapatkan nilai konstanta $\mathrm{Kp}=0.55, \mathrm{Ki}=0.01, \mathrm{Kd}=0.29$ dengan rata-rata waktu respon $=0.7$ detik. 


\section{SARAN}

Dalam penelitian gimbal kamera baru menyelesaikan persoalan 2 sumbu. Oleh karena itu perlu dilakukan penelitian lanjut agar pengambilan gambar dari UAV menjadi lebih baik.

\section{UCAPAN TERIMA KASIH}

Ucapan terimakasih dan penghargaan diberikan kepada Departement Ilmu Komputer dan Elektronika, Fakultas MIPA, Universitas Gadjah Mada yang telah memberi kepercayaan untuk melakukan penelitian dengan memberikan Hibah Dana Penelitian Kontrak No. 0141/J01.1.28/PL.06.02/2016. Ucapan terimakasih juga diberikan kepada Kemenristekdikti atas dukungan dana penelitian dengan Dana PUPT melalui kontrak No. 779/UNI-P.III/LT.DIT$\mathrm{LIT} / 2016$.

Selain itu, ucapan terimakasih dan penghargaan ditujukan kepada Nur Achmad Sulistyo Putro yang telah mendukung penelitian dan membantu menyiapkan manuskrip.

\section{DAFTAR PUSTAKA}

[1] Chen, H., Wang, X.M., dan Li, Y., 2009, A survey of autonomous control for UAV, 2009 Int. Conf. Artif. Intell. Comput. Intell. AICI 2009, vol. 2, pp. 267-271.

[2] Gupte, S., Mohandas, P.I.T., dan Conrad, J.M., 2012. A survey of quadrotor unmanned aerial vehicles, Conf. Proc. - IEEE SOUTHEASTCON.

[3] Mardiatno, D., Khakim, N., dan Priyambodo, T.K., 2016, Identification of flood-prone area using remotely sensed data - Case in Tanjung Selor City, North Kalimantan, in Proceedings of the 2015 IEEE International Conference on Aerospace Electronics and Remote Sensing, ICARES 2015.

[4] Shiino, T., Kawada, K., Yamamoto, T., Komichi, M., dan Nishioka, T., 2008, Gimbals control with the camera for aerial photography in RC helicopter, in 2008 International Conference on Control, Automation and Systems, ICCAS 2008, no. 3, pp. 1135-1139.

[5] Wu, Y.D., Geng, L.C., Zhang, Q., dan Chen, S.L., 2010, Self-adaptive fuzzy PID controller for airborne three-axis pan-tilt, in Advances in Intelligent and Soft Computing, vol. 82 , pp. 553-559.

[6] Abdo, M.M., Vali, A.R., Toloei, A. R., dan Arvan, M. R., 2014, Stabilization loop of a two axes gimbal system using self-tuning PID type fuzzy controller, ISA Trans., vol. 53, no. 2 , pp. 591-602.

[7] Varghese, L., dan Kuncheria, J. T., 2014, Modelling and design of cost efficient novel digital controller for brushless DC motor drive, 2014 Annu. Int. Conf. Emerg. Res. Areas Magn. Mach. Drives, pp. 1-5.

[8] Priyambodo, T.K., Dharmawan, A., Dhewa, O. A., dan Putro, N.A.S., 2016, Optimizing control based on fine tune PID using ant colony logic for vertical moving control of UAV system, in AIP Conference Proceedings, 2016, vol. 1755.

[9] Priyambodo, T.K., Putra, A.E., dan Dharmawan, A., 2015, Optimizing control based on ant colony logic for Quadrotor stabilization, in 2015 IEEE International Conference on 
Aerospace Electronics and Remote Sensing Technology (ICARES), vol. 1, pp. 1-4.

[10] Rajesh, R.J., dan Ananda, C.M., 2015, PSO tuned PID controller for controlling camera position in UAV using 2-axis gimbal, in IEEE International Conference on Power and Advanced Control Engineering, ICPACE 2015, pp. 128-133.

[11] Priyambodo, T.K., Dharmawan, A., dan Putra, A.E., 2016, PID self tuning control based on Mamdani fuzzy logic control for quadrotor stabilization, AIP Conf. Proc., vol. 1705.

[12] Araghi, L.F., Korayem, M.H., Nikoobin, A., dan Setoudeh, F., 2008, Neural Network Controller Based on PID Controller for Two links- Robotic Manipulator Control.

[13] Lu, H., Liu, H., dan Yang, L., 2013, PID Controller Parameter Estimator Using Ant Colony System, in IEEE International Conference on System Science and Engineering, 2013, pp. 319-324.

[14] Åström, K.J., dan Hägglund, T., 2004, Revisiting the Ziegler-Nichols step response method for PID control, J. Process Control, vol. 14, no. 6, pp. 635-650.

[15] Ogata, K., 2010, Modern Control Engineering, $5^{\text {th }}$ eds., Prentice-Hall. 